\title{
Productivity and Real Exchange Rates: Some Empirical Examples
}

\author{
Manuchehr Irandoust \\ University of Örebro \\ Boo Sjöö \\ University College of Skövde
}

\begin{abstract}
This paper examines the relevance of the Balassa-Samuelson productivity-bias hypothesis for explaining long-run permanent shocks in the real exchange rates. The sample consists of yearly data on real exchange rates and productivity for six OECD countries. On the basis of Johansens maximum likelihood tests and VECMs, we find little support for the hypothesis. Our results provide a weak support for monetary integration in Europe.
\end{abstract}

- JEL Classifications: E31, F31, F41, C32

- Key Words: Real Exchange Rate, Productivity Differential, Cointegration, BalassaSamuelson's Effect, Johansen's Technique.

\section{Introduction}

The competitiveness of a country is often measured by its real exchange rate. This has its origin in the theorem of purchasing power parity (PPP), one of the oldest hypotheses in economics. Its foundation can be found in the thoughts of David Hume and its modern introduction has been attributed to Cassel (1916). The

*Corresponding address: Manuchehr Irandoust, Department of Economics, University of Örebro, SE-701 82, Örebro, Sweden, Tel: +46-19-30-33-98, Fax: +46-19-33-25-46, E-mail: manuchehr.irandoust@esa.oru.se Boo Sjöö, Department of Economics, University of College of Skövde, P.O. Box 408, SE-541 28 , Skövde, Sweden, Tel: +46-500-448723, Fax: +46-500-448799, E-mail: boo.sjoo@ish.his.se

${ }^{1}$ Manuchehr Irandoust is Associate Professor at the Department of Economics, University of Örebro, Sweden.

(C)2002-Center for International Economics, Sejong Institution, All Rights Reserved. 
PPP theorem in its "absolute" version asserts that the long-run equilibrium exchange rate between two countries currencies is equal to the ratio of their price levels. In other words, the PPP theorem implies that in the long run, two countries price levels are equal when converted to a common currency, or that the real exchange rate is equal to unity. "Relative" PPP asserts that the real exchange rate is constant, although it need not be one. Therefore, fluctuations in the real exchange rate are synonymous with deviations from long-run PPP.

In this paper, we study the long-run behaviour of the real exchange rate by adopting a permanent-transitory decomposition in which the real exchange rate covaries with a set of nonstationary productivity series, in line with the work of Balassa (1964) and Samuelson (1964). We use vector error-correction models (VECMs) as a basis for testing if permanent shocks in real exchange rates cointegrate with permanent shocks in productivity. Different specifications are imposed to improve estimation and prediction precision. If as Balassa has suggested, the two countries being examined have experienced large differences in productivity growth, this may generate a trend in the real exchange rate, that can be tested explicitly.

The classical model of the real exchange rate, which was developed by Balassa (1964) and Samuelson (1964), suggested that deviations between any exchange rate and its PPP value stem from productivity differentials between the nontraded and traded sectors of economies. Such a gap in productivity performance will affect real exchange rates if productivity growth is concentrated in the traded sectors of both countries. Consequently, the prices of traded relative to nontraded goods must adjust through time in order to indicate productivity gains. Theoretically, the existence of productivity differences between countries is an important reason for a divergence between PPP and the equilibrium exchange rate. Greater difference between the productivity of two countries which leads to a larger gap between their wages may create a larger gap between PPP and the equilibrium exchange rate. Real exchange-rate changes in response to productivity growth differentials have been labelled in the literature as the "productivity-bias hypothesis" or "Balassa-Samuelson effect", reflecting the view that an increase or a decrease in a country's relative productivity creates an appreciation or a depreciation of its real exchange rate (Balassa, 1964; Samuelson, 1964; Officer, 1976).

Existing empirical research on productivity-bias hypothesis has produced mixed results. Among the studies that have supported the hypothesis can be cited those by Balassa (1964), Hsieh (1982), Edison and Klovland (1987), Marston (1987), Obstfeld (1993), and De Gregorio et al. (1994). The conclusion that can be derived 
from these studies is that the deviation of the real exchange rate from its timevarying, long-run equilibrium value is a function of productivity or real shocks. Others such as Froot and Rogoff (1991a, b), Rogers (1995), Rogers and Jenkins (1995), Mark and Choi (1997) have little or no support for the productivity-bias hypothesis. As a whole, these studies employ different estimation techniques and attempt to explain many stylised facts, such as the observed variations or trends in real exchange rates and comovements between real exchange rates and real shocks. The results, however, are mixed and highly sensitive to the year chosen and to the countries included in the regressions.

A number of the previous studies has focused mainly on estimating models using cross-sectional data based on the implicit assumption that countries have common characteristics. This may not be true because countries differ not only in their institutional, political, and economic structures but also in their reactions to external shocks. Thus, the estimates from cross-sectional regressions are misleading because they do not consider country-specific characteristics. On the other hand, with a few exceptions, the problem with the previous studies is that their conclusions are based on non-stationary data. In other words, very little consideration is given in terms of evaluating the time series characteristics (stationarity and cointegration) of the data employed. The application of conventional econometric techniques to non-stationary (integrated) time series can give rise to misleading results and erroneous inferences (Sims et al., 1990). Generally speaking, the existing time-series studies pay only little attention both to the presence of trends in the data and to dynamic VECMs which allow for inference on exogeneity and causality concepts. Most of the empirical literature is not explicitly dynamic and tests of long-run real exchange-rate dynamics under the Balassa-Samuelson effect are not that common.

Does productivity performance explain long-run deviations from PPP? The purpose of our work is to examine a time series analysis of the productivity-bias hypothesis in PPP by assessing a long-run cointegrating relationship between productivity growth differentials and real exchange rates. Our sample countries consist of Denmark, Germany, Norway, Sweden, the UK, and the US. The data used in this study are annual observations and cover the period 1960-1995.

\section{Theoretical Background}

The model used in this paper follows Froot and Rogoff (1991b, 1995) and Mark 
and Choi (1997). The PPP theorem has specific implications for the time-series behavior of the $(\log )$ real exchange rate, $\Phi_{t}$, defined as

$$
\Phi_{t}=S_{t} P_{t}^{*} / P_{t}
$$

where $S_{t}$ is defined as the exchange rate of domestic currency per unit of foreign currency and $P_{t}$ and $P_{t}^{*}$ are the domestic and foreign prices, respectively. For PPP to hold the real exchange rate $\Phi_{t}$ must have a constant mean and the tendency to revert to that mean, implying that the real exchange rate must be level stationary. If the real exchange rate has a unit root, absolute PPP given by the equation $S_{t}=P_{t} / P_{t}^{*}$ can not be regarded as an equilibrium. It is possible that the real exchange rate will have deviations from its equilibrium level in the short run, due possibly to the differences in adjustment rates of price indices and asset prices. But in the long run, the real exchange rate must return to its equilibrium level for PPP to hold. For simplicity, the $(\log )$ real exchange rate, $\Phi_{t}$, is decomposed into two terms as

$$
\Phi_{t}=\bar{\Phi}_{t}-u_{t}
$$

where $\bar{\Phi}_{t}$ is the long-run equilibrium value and $u_{t}$ is an error term. Alternative views of the real exchange rate process are embedded in equation (2). Under the random-walk model, it is possible to have $\bar{\Phi}_{t}=\bar{\Phi}_{t-1}+z_{t}$, with $\left\{z_{t}\right\}$ a serially uncorrelated sequence and var $\left(u_{t}\right)=0$. Thus, long-run PPP can be shown with a constant valued $\bar{\Phi}_{t}$ and $\left(u_{t}\right)$ being a serially correlated covariance stationary process. Under PPP, the long-run value of the real exchange rate, $\bar{\Phi}_{t}$, is constant under the assumption that $\left\{\Phi_{t}\right\}$ is stationary.

Balassa (1964) and Samuelson (1964) consider a small open economy that produces traded and nontraded goods. ${ }^{1}$ Assume that the $(\log )$ price level is $p=\omega p^{T}+(1-\omega) p^{N}$ where $p^{T}$ is the $(\log )$ local currency price of tradables, $\omega$ is the domestic consumption share of tradables, and $p^{N}$ is the (log) local currency price of nontradables. The (log) real exchange rate can be separated into the (log) real exchange rate for traded goods, the $(\log )$ relative price between tradables and nontradables at home and the $(\log )$ relative price between tradables and nontradables abroad, i.e.,

$$
\bar{\Phi}_{t}=\left(s_{t}+p_{t}^{* T}-p_{t}^{T}\right)+(1-\omega)\left(p_{t}^{T}-p_{t}^{N}\right)-\left(1-\omega^{*}\right)\left(p_{t}^{{ }^{* T}}-p_{t}^{* N}\right)
$$

Under the Balassa-Samuelson tradition, the real exchange rate is determined 
entirely by the production technology if (i) the law of one price holds among traded goods so that the first term in equation (3) disappears; (ii) the terms of trade are constant; (iii) capital can be transferred across countries; (iv) production functions for sectors are represented by constant returns to scale; (v) there are free movements of production factors between sectors. However, the long-run value can be represented as:

$$
\bar{\Phi}_{t}=\theta_{0}+\theta_{1} \gamma_{t}
$$

where $\gamma_{t}$ denotes productivity growth. The Balassa-Samuelson model, in which differences in productivity growth can lead to real exchange rate changes may provide a rationale for random walk exchange rate behavior. If productivity differential shocks are permanent, productivity shocks can result in a unit root in the real exchange rate. In Rogoff's (1992) model, in which intertemporal smoothing of traded goods consumption can lead to smoothing of the intertemporal price of traded and nontraded goods, even transitory productivity shocks can result in a

The central equation of the Balassa-Samuelson hypothesis is derived as follows. Assume that the sectoral production functions are:

$$
\begin{aligned}
& Q_{t}^{T}=A_{t}^{T}\left(L_{t}^{T}\right)^{\varphi^{T}}\left(K_{t}^{T}\right)^{1-\varphi^{T}}, \\
& Q_{t}^{N}=A_{t}^{N}\left(L_{t}^{N}\right)^{\varphi^{N}}\left(K_{t}^{N}\right)^{1-\varphi^{N}}
\end{aligned}
$$

where $Q^{T}\left(Q^{N}\right)$ indicate domestic output of the traded and nontraded goods respectively, and $K^{i}, L^{i}$ and $A^{i}$ denote capital, labour and productivity in sector $i$. Profit maximization implies:

$$
\begin{gathered}
R=\left(1-\varphi^{T}\right) A^{T}\left(K^{T} / L^{T}\right)^{-\varphi^{T}}, \\
R=P^{N}\left(1-\varphi^{N}\right) A^{N}\left(K^{N} / L^{N}\right)^{-\varphi^{T}}, \\
W=\varphi^{T} A^{T}\left(K^{T} / L^{T}\right)^{1-\varphi^{T}} \\
W=P^{N} \varphi^{N} A^{N}\left(K^{N} / L^{N}\right)^{1-\varphi^{N}}
\end{gathered}
$$

where $R$ and $W$ are the rental rate on capital and the wage rate respectively, and $P^{N}$ is the relative price of nontradables. By log-differentiating eqs. (3a)-(6a), a generalization of the classic Balassa-Samuelson effect can be obtained:

$$
\hat{P}=\left(\varphi^{N} / \varphi^{T}\right) \hat{\gamma}^{T}-\hat{\gamma}^{N}
$$

where $\hat{x} \equiv d \log x$. If the degree of capital intensity is the same in both sectors $\left(\varphi^{N}=\varphi^{T}\right)$, then the percentage change in the relative price of traded goods equals the productivity growth differential between the traded and nontraded sectors $\left(\hat{\gamma}^{T}-\hat{\gamma}^{N}\right)$. If, however, nontraded goods are more labor intensive $\left(\varphi^{N}>\varphi^{T}\right)$, then even the same productivity growth across the two sectors $\left(\hat{\gamma}^{T}=\hat{\gamma}^{N}\right)$ will create an appreciation of the relative price of traded goods. 
unit root in the real exchange rate. Taken as a whole, cointegration is to be expected under the hypothesis namely that if productivity levels are converging between two countries this will create an equilibrium real exchange rate in the long run.

\section{Methodology, Data, and Empirical Models}

To identify statistically the long-run relations between the real exchange rates and the measures of productivity requires formulating a well-defined statistical vector error-correction model (VECM). We then use the Johansen (1988) and Johansen and Juselius (1990) approach to test for the number of cointegrating vectors and to identify these vectors as economically meaningful relationships. The Johansen procedure is based on the error-correction representation of the vector autoregression VAR $(k)$ model with Gaussian errors, i.e.:

$$
X_{t}=\Pi_{1} X_{t-1}+\Pi_{2} X_{t-2}+\ldots+\Pi_{k} X_{t-k}+\xi_{t}
$$

where $X$ is an $N \times 1$ vector of $I(1)$ variables. The long-run static equilibrium associated with equation (5) is $\Pi X=0$, where the long-run coefficient matrix $\Pi$ is defined as

$$
\Pi=-\left(I-\Pi_{1}-\Pi_{2}-\ldots-\Pi_{k}\right)
$$

The long-run cointegrating matrix $\Pi$ is an $N \times N$ matrix whose rank determines the number of cointegrating vectors, say $r$. If we define two matrices $\alpha(N \times r)$ and $\beta(N \times r)$ such that $\Pi=\alpha \beta^{\prime}$, the rows of $\beta$ will form the $r$ cointegrating vectors. Johansen and Juselius (1990) introduce two likelihood-ratio tests known as the $\lambda$ max and trace tests to determine the number of cointegrating vectors using the maximum likelihood estimates of cointegrating vectors.

The data used in this study are annual observations and cover the period 19601995. The real exchange rates and productivity series look non-stationary. Thus, we will assume that they are integrated of order one, unless we find evidence that clearly rejects this assumption. The real exchange rate is defined as $\Phi_{i j t}=\ln P_{j t}+$ $\ln S_{i j t}-\ln P_{i t}$ where $P_{j t}$ is the price level in country $j$ at time $t$ - the foreign country - and $P_{i t}$ is the price level in the domestic country. The nominal foreign exchange rate $\left(S_{i j t}\right)$ is defined as domestic currency units per one foreign currency unit. The exchange rate series is derived from the OECD Main Economic Indicators (various issues). The price levels in this study are gross domestic product (GDP) 
deflators taken from the OECD Economic Outlook (various issues). The sample of countries consists of Denmark, Germany, Norway, Sweden, the UK, and the US. Real exchange rates are calculated against the US and Germany.

The yearly productivity series, constructed as GDP per employed worker, is collected from the OECD Economic Outlook (various issues). By inspecting the data, we found a clear break for Germany in 1991, the year that East- and WestGermany reunited. Thus, a dummy variable for the year 1991 appears to be motivated. The "productivity gap" between country $i$ and $j$ is defined as $\gamma_{i j l}=\ln$ $P R O D_{j}-\ln P R O D_{i}$, where $j$ is the source country, either the US or Germany, and PROD stands for productivity.

The models considered here attempt to explain the effect of productivity differentials on the real exchange rate. For each country we will try to find a VECM that is consistent with the data chosen in this paper. The theoretical considerations discussed in Section 2 result in the following (possible) cointegrating relationship

$$
\Phi_{i j t}=\beta_{0}+\beta_{1} \gamma_{i j t}
$$

where $\Phi_{i j t}$ is the log of real exchange rate for country $i$ against country $j$, and $\gamma_{i j t}$ is the productivity gap between country $i$ and $j,\left(\log P R O D_{j}-\log P R O D_{i}\right)$. A significant positive $\beta_{1}$ coefficient, in this cointegrating vector, indicates support for the productivity-bias hypothesis. A less restricted version of this relationship allows both for separate coefficients on the productivity variables and for a possible time trend,

$$
\Phi_{i j t}=\beta_{0}+\beta_{1} \operatorname{prod}_{j t}+\beta_{2} \operatorname{prod}_{i t}+\beta_{3} t
$$

These models do not work well for our sample countries. Testing for cointegration between bivariate real exchange rates towards Germany or the US, leads to problems in finding well-defined statistical VECM representation, but also in identifying the significant cointegration vectors. The reason for this failure might be that the productivity-bias is mainly relevant for effective exchange rates. Further, many countries have used baskets or target zones as a basis for their foreign exchange rate regimes. Thus, the relevant price comparisons are therefore between some weighted average of countries rather than bivariate comparisons. To test this hypothesis we look for a cointegration vector of the type,

$$
\Phi_{i, u s, t}=\beta_{0}+\beta_{1} \gamma_{i, u s, t}+\beta_{2} \gamma_{i, g e r, t}+\beta_{3} \Phi_{i, g e r, t}
$$


Table 1. Productivity Index - Dickey-Fuller Tests for One Unit Root ${ }^{\mathrm{a}}$ Test statistics calculated from models with constant and trend terms.

\begin{tabular}{|c|c|c|c|c|c|}
\hline \multirow[t]{2}{*}{ Variable } & & \multicolumn{4}{|c|}{ Lag number } \\
\hline & & 0 & 1 & 2 & 3 \\
\hline \multicolumn{6}{|l|}{ Germany } \\
\hline \multirow[t]{2}{*}{ lprod_G } & ADF-value & -1.83 & -1.65 & -1.52 & -1.06 \\
\hline & p-value & - & 0.34 & 0.73 & 0.14 \\
\hline \multicolumn{6}{|l|}{ Denmark } \\
\hline \multirow[t]{2}{*}{ lprod_D } & ADF-value & $-4.25 * *$ & $-4.18^{*}$ & $-4.34 * *$ & $-4.07 *$ \\
\hline & p-value & - & 0.97 & 0.12 & 0.38 \\
\hline \multicolumn{6}{|l|}{ Norway } \\
\hline \multirow[t]{2}{*}{ lprod_N } & ADF-value & -2.59 & -2.58 & -2.80 & -2.68 \\
\hline & p-value & - & 0.27 & 0.73 & 0.02 \\
\hline \multicolumn{6}{|l|}{ Sweden } \\
\hline \multirow[t]{2}{*}{ lprod_S } & ADF-value & -3.21 & -3.03 & -2.96 & -2.84 \\
\hline & p-value & - & 0.09 & 0.61 & 0.03 \\
\hline \multicolumn{6}{|l|}{ UK } \\
\hline \multirow[t]{2}{*}{ lprod_UK } & ADF-value & -2.49 & -2.69 & -2.05 & -1.93 \\
\hline & p-value & - & 0.25 & 0.16 & 0.99 \\
\hline \multicolumn{6}{|l|}{ US } \\
\hline \multirow[t]{2}{*}{ lprod_US } & ADF-value & $-4.27 * *$ & $-4.23^{*}$ & $-4.18^{*}$ & $-4.11 *$ \\
\hline & $\mathrm{p}$-value & - & 0.50 & 0.74 & 0.82 \\
\hline
\end{tabular}

Models include constants but no deterministic trend. lprod is log of productivity index. Yearly data 1960-1995. P-values refer to probability value of the lag in the augmentation.

where $\Phi_{i, u s, t}$ is the real exchange rate for country $i$ towards the US, $\gamma_{i, u s, t}$ is the productivity gap between country $i$ and the US, $\gamma_{i, g e r, t}$ is the productivity gap between country $i$ and Germany, and $\Phi_{i, g e r t}$ is the real exchange rate between country $i$ and Germany. For most European countries, the US dollar and the German mark are the two most important currencies. Equation 9 therefore captures the most important currencies for constructing an efficient real exchange rate adjusted for productivity bias.

\section{Estimation Results}

The first question is how to describe the nonstationary behaviour of the series in a statistical model. Tables 1-5 present the results of augmented Dickey-Fuller tests, showing that we cannot easily reject the assumption of I(1) processes for the real exchange rate series, the individual productivity series and for the productivity gaps towards Germany and the US. The exception here is the real Deutsche mark 
Table 2. Productivity Index - Dickey-Fuller Tests for One Unit Root ${ }^{\mathrm{a}}$ Test statistics calculated from model with a constant term.

\begin{tabular}{|c|c|c|c|c|c|}
\hline \multirow[t]{2}{*}{ Variable } & & \multicolumn{4}{|c|}{ Lag number } \\
\hline & & 0 & 1 & 2 & 3 \\
\hline \multicolumn{6}{|l|}{ Germany } \\
\hline \multirow{2}{*}{ lprod_G } & ADF-value & $-3.25^{*}$ & $-3.47 *$ & $-3.29 *$ & $-3.69 * *$ \\
\hline & $\mathrm{p}$-value & - & 0.25 & 0.61 & 0.14 \\
\hline \multicolumn{6}{|l|}{ Denmark } \\
\hline \multirow[t]{2}{*}{ lprod_D } & ADF-value & -2.90 & -2.83 & $-3.25^{*}$ & -2.24 \\
\hline & p-value & - & 0.79 & 0.14 & 0.36 \\
\hline \multicolumn{6}{|l|}{ Norway } \\
\hline \multirow[t]{2}{*}{ lprod_N } & ADF-value & -1.93 & -1.67 & -1.83 & -2.73 \\
\hline & $\mathrm{p}$-value & - & 0.48 & 0.34 & 0.02 \\
\hline \multicolumn{6}{|l|}{ Sweden } \\
\hline \multirow[t]{2}{*}{ lprod_S } & ADF-value & -1.90 & -1.17 & -1.34 & -0.56 \\
\hline & $\mathrm{p}$-value & - & 0.03 & 0.45 & 0.12 \\
\hline \multicolumn{6}{|l|}{ UK } \\
\hline \multirow[t]{2}{*}{ lprod_UK } & ADF-value & -1.49 & -1.32 & -1.76 & -1.82 \\
\hline & $\mathrm{p}$-value & - & 0.59 & 0.03 & 0.59 \\
\hline \multicolumn{6}{|l|}{ US } \\
\hline \multirow[t]{2}{*}{ lprod_US } & ADF-value & -2.45 & -2.20 & -2.09 & -2.03 \\
\hline & $\mathrm{p}$-value & - & 0.73 & 0.83 & 0.78 \\
\hline
\end{tabular}

Models include constants but no deterministic trend. lprod is log of productivity index.

P-values refer to probability value of the lag in the augmentation.

(DM) exchange rate for Denmark, which can be seen as stationary around deterministic trends.

In the second step we analyse the cointegrating properties of the productivity series. The outcome of testing for cointegration among the six productivity series is presented in Table 6 . The test statistics suggest three or four cointegrating vectors, implying that there are three or two common trends in the system. The VECMs display vector-residual autocorrelation, originating from the US series. If the US series is excluded, the vector autoregression (VAR) passes all the tests. Given the limited sample it's not possible to increase the lag length, nor could we find suitable dummy variables that "remove" the significant autocorrelation. Though the VAR of the total sample does not fit as much as we would like, we choose to analyse this model because it seems to encompass the results of the model without US productivity. Adding the US series to the VAR does not change the results, except for leading to a rejection of the assumption of no residual autocorrelation. 
Table 3A. Real DM Exchange Rate - Dickey-Fuller: Tests for One Unit Root ${ }^{\mathrm{a}}$ Test statistics calculated from models with constant and trend terms

\begin{tabular}{|c|c|c|c|c|c|}
\hline \multirow[t]{2}{*}{ Variable } & & \multicolumn{4}{|c|}{ Lag number } \\
\hline & & 0 & 1 & 2 & 3 \\
\hline \multicolumn{6}{|l|}{ Denmark } \\
\hline \multirow[t]{2}{*}{$r e \_D G$} & ADF-value & -2.05 & -2.98 & $-3.95 * *$ & $-5.02 * *$ \\
\hline & p-value & - & 0.02 & 0.03 & 0.02 \\
\hline \multicolumn{6}{|l|}{ Norway } \\
\hline \multirow[t]{2}{*}{$r e \_N G$} & ADF-value & -1.49 & -2.65 & -1.12 & -1.34 \\
\hline & p-value & - & 0.01 & 0.08 & 0.45 \\
\hline \multicolumn{6}{|l|}{ Sweden } \\
\hline \multirow[t]{2}{*}{$r e \_s G$} & ADF-value & -2.35 & -3.73 & -2.00 & -2.59 \\
\hline & p-value & - & 0.01 & 0.49 & 0.10 \\
\hline \multicolumn{6}{|l|}{ UK } \\
\hline \multirow[t]{2}{*}{ re_UKG } & ADF-value & -1.54 & -2.10 & -1.74 & -2.27 \\
\hline & p-value & - & 0.06 & 0.64 & 0.07 \\
\hline \multicolumn{6}{|l|}{ US } \\
\hline \multirow[t]{2}{*}{ re_GUS } & ADF-value & -1.69 & -2.50 & -2.23 & -2.19 \\
\hline & p-value & - & 0.02 & 0.98 & 0.66 \\
\hline
\end{tabular}

Models include constant and a deterministic trend. Yearly data 1960-1995. re is real DM exchange rate, except for Germany (re_GUS) which is real USD exchange rate. P-values refer to probability value of the lag in the augmentation.

Table 3B. Real DM Exchange Rate - Dickey-Fuller: Tests for One Unit Root ${ }^{\mathrm{a}}$ Test statistics calculated from model with a constant term.

\begin{tabular}{|c|c|c|c|c|c|}
\hline \multirow[t]{2}{*}{ Variable } & & \multicolumn{4}{|c|}{ Lag number } \\
\hline & & 0 & 1 & 2 & 3 \\
\hline \multicolumn{6}{|l|}{ Denmark } \\
\hline \multirow[t]{2}{*}{$r e \_D G$} & ADF-value & -1.55 & -2.54 & $-3.48 *$ & $-4.14 * *$ \\
\hline & $\mathrm{p}$-value & - & 0.06 & 0.58 & 0.10 \\
\hline \multicolumn{6}{|l|}{ Norway } \\
\hline \multirow[t]{2}{*}{$r e \_N G$} & ADF-value & -0.90 & -2.13 & -0.63 & -0.89 \\
\hline & $\mathrm{p}$-value & - & 0.01 & 0.08 & 0.48 \\
\hline \multicolumn{6}{|l|}{ Sweden } \\
\hline \multirow[t]{2}{*}{$r e \_S G$} & ADF-value & -0.92 & -1.61 & -0.07 & -0.18 \\
\hline & $\mathrm{p}$-value & - & 0.11 & 0.03 & 0.58 \\
\hline \multicolumn{6}{|l|}{ UK } \\
\hline \multirow[t]{2}{*}{$r e \_U K G$} & ADF-value & -1.49 & -2.00 & -1.64 & -2.04 \\
\hline & $\mathrm{p}$-value & - & 0.06 & 0.58 & 0.10 \\
\hline \multicolumn{6}{|l|}{ US } \\
\hline re_GUS & ADF-value & -1.11 & -1.53 & -1.29 & -1.19 \\
\hline & $\mathrm{p}$-value & - & 0.05 & 0.56 & 0.88 \\
\hline
\end{tabular}

Models include constants but no deterministic trend. Yearly data 1960-1995. $r e$ is real DM exchange rate, except for Germany (re_GUS) which is real USD exchange rate. P-values refer to probability value of the lag in the augmentation. 
Table 4A. Productivity Gap against the US - Dickey-Fuller: Tests for One Unit Root ${ }^{\mathrm{a}}$ Test statistics calculated from models with constant and trend terms. Productivity gap is log of domestic productivity index minus log of German productivity index.

\begin{tabular}{|c|c|c|c|c|c|}
\hline \multirow[t]{2}{*}{ Variable } & & \multicolumn{4}{|c|}{ Lag number } \\
\hline & & 0 & 1 & 2 & 3 \\
\hline \multicolumn{6}{|l|}{ Denmark } \\
\hline \multirow[t]{2}{*}{$p d i f \_D$} & ADF-value & -2.43 & -1.90 & -1.58 & -2.30 \\
\hline & $\mathrm{p}$-value & - & 0.28 & 0.47 & 0.02 \\
\hline \multicolumn{6}{|l|}{ Norway } \\
\hline \multirow[t]{2}{*}{$p d i f \_N$} & ADF-value & -2.13 & -2.07 & -2.18 & -1.74 \\
\hline & p-value & - & 0.34 & 0.71 & -0.70 \\
\hline \multicolumn{6}{|l|}{ Sweden } \\
\hline \multirow[t]{2}{*}{$p d i f \_S$} & ADF-value & -2.37 & -2.63 & -2.13 & -2.16 \\
\hline & p-value & - & 0.27 & 0.53 & 0.60 \\
\hline \multicolumn{6}{|l|}{ UK } \\
\hline \multirow[t]{2}{*}{ pdif_UK } & ADF-value & -2.54 & -3.38 & -2.55 & -3.49 \\
\hline & p-value & - & 0.03 & 0.15 & 0.01 \\
\hline \multicolumn{6}{|l|}{ Germany } \\
\hline \multirow[t]{2}{*}{$p d i f \_G$} & ADF-value & -1.10 & -0.83 & -0.88 & -0.49 \\
\hline & p-value & - & 0.48 & 0.75 & 0.57 \\
\hline
\end{tabular}

Models include constant and a deterministic trend. Yearly data 1960-1995. pdif is the productivity gap in logs against the US. P-value refers to probability values of the lag in the augmentation.

Table 4B. Productivity Gap against the US - Dickey-Fuller: Tests for One Unit Root ${ }^{\mathrm{a}}$ Test statistics calculated from models with a constant term. Productivity gap is log of domestic productivity index minus log of German productivity index.

\begin{tabular}{|lllrrr|}
\hline Variable & & \multicolumn{4}{c|}{ Lag number } \\
\hline Denmark & & 0 & 1 & 2 & 3 \\
pdif_D & ADF-value & -1.36 & -1.28 & -1.26 & -1.15 \\
& p-value & - & 0.09 & 0.25 & 0.08 \\
Norway & & & & -0.44 & -0.27 \\
pdif_N & ADF-value & -0.49 & -0.45 & 0.98 & 0.18 \\
& p-value & - & 0.68 & & \\
Sweden & & & & -0.70 & -0.68 \\
pdif_S & ADF-value & -0.80 & -0.81 & 0.15 & 0.97 \\
UK & p-value & - & 0.81 & & -0.24 \\
pdif_UK & ADF-value & -0.31 & -0.39 & -0.04 & 0.06 \\
Germany & p-value & - & 0.41 & 0.02 & -2.23 \\
pdif_G & ADF-value & -2.31 & -2.36 & -2.23 & 0.68 \\
\hline
\end{tabular}

Models include constants but no deterministic trend. Yearly data 1960-1995. pdif is the productivity gap against Germany, except $p \operatorname{dif} U S G$ which is $\log$ of German productivity minus log of US productivity. P-value refers to probability values of the lag in the augmentation. 
Table 5A. Productivity Gap against Germany - Dickey-Fuller: Tests for One Unit Root ${ }^{\mathrm{a}}$ Test statistics calculated from models with constant and trend terms. Productivity gap is log of domestic productivity index minus log of German productivity index

\begin{tabular}{|lllrrr|}
\hline Variable & & \multicolumn{5}{c|}{ Lag number } \\
\hline Denmark & & 0 & 1 & 2 & 3 \\
pdif_DG & ADF-value & -1.20 & -0.71 & -0.53 & -0.44 \\
& p-value & - & 0.39 & 0.84 & 0.99 \\
Norway & & & & -1.72 & -0.84 \\
pdif_NG & ADF-value & -1.76 & -1.63 & 0.55 & 0.21 \\
& p-value & - & 0.96 & & \\
Sweden & & & & -0.41 & -0.21 \\
pdif_SG & ADF-value & -0.55 & -0.31 & 0.77 & 0.78 \\
& p-value & - & 0.68 & -0.88 & -0.49 \\
UK & ADF-value & -1.10 & -0.83 & 0.75 & 0.57 \\
pdif_UK & p-value & - & 0.48 & & \\
US & ADF-value & -1.10 & -0.83 & -0.88 & -0.49 \\
pdif_USG & p-value & - & 0.48 & 0.75 & 0.57 \\
& & & & & \\
\end{tabular}

Models include constant and a deterministic trend. Yearly data 1960-1995. pdif is the productivity gap against Germany, except pdifUSG which is log of German productivity minus log of US productivity. Pvalues refer to probability values of the lag in the augmentation.

Table 5B. Productivity Gap against Germany - Dickey-Fuller: Tests for One Unit Root ${ }^{\mathrm{a}}$ Test statistics calculated from models with a constant term. Productivity gap is log of domestic productivity index minus log of German productivity index.

\begin{tabular}{|c|c|c|c|c|c|}
\hline \multicolumn{3}{|l|}{ Variable } & \multicolumn{3}{|c|}{ Lag number } \\
\hline & & 0 & 1 & 2 & 3 \\
\hline \multicolumn{6}{|l|}{ Denmark } \\
\hline \multirow[t]{2}{*}{ pdif_DG } & ADF-value & -1.66 & -1.47 & -1.50 & -1.60 \\
\hline & p-value & - & 0.67 & 0.69 & 0.57 \\
\hline \multicolumn{6}{|l|}{ Norway } \\
\hline \multirow[t]{2}{*}{$p d i f \_N G$} & ADF-value & -0.41 & -0.41 & -0.74 & -0.00 \\
\hline & p-value & - & 0.92 & 0.44 & 0.30 \\
\hline \multicolumn{6}{|l|}{ Sweden } \\
\hline \multirow[t]{2}{*}{ pdif_SG } & ADF-value & -1.63 & -1.61 & -1.69 & -1.67 \\
\hline & p-value & - & 0.92 & 0.44 & 0.30 \\
\hline \multicolumn{6}{|l|}{ UK } \\
\hline \multirow[t]{2}{*}{ pdif_UKG } & ADF-value & -2.31 & -2.36 & -2.23 & -2.23 \\
\hline & p-value & - & 0.53 & 0.65 & 0.68 \\
\hline \multicolumn{6}{|l|}{ US } \\
\hline pdif_USG & ADF-value & -2.31 & -2.36 & -2.23 & -2.23 \\
\hline & p-value & - & 0.53 & 0.65 & 0.68 \\
\hline
\end{tabular}

Models include constants but no deterministic trend. Yearly data 1960-1995. pdif is the productivity gap against Germany, except pdifUSG which is log of German productivity minus log of US productivity. Pvalues refer to probability values of the lag in the augmentation. 
Table 6. Testing Cointegration among productivity series

\begin{tabular}{rrrrrrr}
\hline Eigenv. & $\lambda$-max & Trace & HO: $r$ & $p$ - $r$ & \multicolumn{3}{c}{$\lambda$-max90 } & Trace90 \\
0.8779 & 69.41 & 193.19 & 0 & 6 & 24.63 & 89.37 \\
0.7238 & 42.46 & 123.78 & 1 & 5 & 20.90 & 64.74 \\
0.6887 & 38.51 & 81.32 & 2 & 4 & 17.15 & 43.84 \\
0.6116 & 31.21 & 42.81 & 3 & 3 & 13.39 & 26.70 \\
0.2963 & 11.60 & 11.60 & 4 & 2 & 10.60 & 13.31 \\
0.0001 & 0.00 & 0.00 & 5 & 1 & 2.71 & 2.71
\end{tabular}

Test for vector residual autocorrelation

$\mathrm{L}-\mathrm{B}(8), \quad \operatorname{chisq}(192)=408.34, \mathrm{p}-\mathrm{val}=0.00$

$\mathrm{LM}(1), \quad \operatorname{chisq}(36)=76.70, \mathrm{p}-\mathrm{val}=0.00$

$\mathrm{LM}(4), \quad \operatorname{chisq}(36)=36.41, \mathrm{p}-\mathrm{val}=0.45$

Test for normality

$\operatorname{chisq}(12) \quad=8.522, \mathrm{p}-\mathrm{val}=0.74$

$\begin{array}{ccc}\text { ARCH(3) } & \text { Normality } & R \text {-squared } \\ 0.865 & 1.247 & 0.688 \\ 3.493 & 2.062 & 0.853 \\ 2.240 & 0.663 & 0.543 \\ 3.391 & 0.313 & 0.914 \\ 2.379 & 6.639 & 0.565 \\ 0.401 & 2.554 & 0.376\end{array}$

The eigenvalues of the companion matrix real complex modulus argument
$\begin{array}{llll}1.0102 & 0.0000 & 1.0102 & 0.0000\end{array}$
$\begin{array}{llll}0.9807 & 0.0000 & 0.9807 & 0.0000\end{array}$
$\begin{array}{llll}0.2962 & 0.7877 & 0.8415 & 1.2112\end{array}$
$\begin{array}{llll}0.2962 & -0.7877 & 0.8415 & -1.2112\end{array}$
$\begin{array}{llll}0.7713 & -0.2944 & 0.8255 & -0.3646\end{array}$
$\begin{array}{llll}0.7713 & 0.2944 & 0.8255 & 0.3646\end{array}$
$\begin{array}{llll}-0.2925 & 0.7292 & 0.7856 & 1.9523\end{array}$
$\begin{array}{llll}-0.2925 & -0.7292 & 0.7856 & -1.9523\end{array}$
$\begin{array}{llll}-0.1057 & 0.7519 & 0.7593 & 1.7105\end{array}$
$\begin{array}{llll}-0.1057 & -0.7519 & 0.7593 & -1.7105\end{array}$
$\begin{array}{llll}0.5143 & -0.4610 & 0.6906 & -0.7308\end{array}$
$\begin{array}{llll}0.5143 & 0.4610 & 0.6906 & 0.7308\end{array}$
$\begin{array}{llll}-0.6624 & 0.0000 & 0.6624 & 3.1416\end{array}$
$\begin{array}{llll}-0.5989 & 0.0000 & 0.5989 & 3.1416\end{array}$
$\begin{array}{llll}0.5567 & 0.0000 & 0.5567 & 0.0000\end{array}$
$\begin{array}{llll}0.3873 & 0.0000 & 0.3873 & 0.0000\end{array}$
$\begin{array}{llll}-0.1968 & 0.0829 & 0.2136 & 2.7432\end{array}$
$\begin{array}{llll}-0.1968 & -0.0829 & 0.2136 & -2.7432\end{array}$ 
Table 6. Continued

\begin{tabular}{lrllllllrr}
\hline Alpha-parameters & & \multicolumn{7}{c}{$t$-values for alpha parameters } \\
DLPROD_D & -0.717 & -0.267 & -0.093 & 0.010 & -2.750 & -4.767 & -2.475 & 1.030 \\
DLPROD_S & 0.488 & -0.316 & -0.074 & -0.017 & 2.573 & -7.755 & -2.698 & -2.469 \\
DLPROD_N & 0.913 & -0.108 & 0.007 & 0.013 & 3.105 & -1.718 & 0.159 & 1.219 \\
DLPROD_G & -0.336 & -0.284 & -0.009 & 0.025 & -1.351 & -5.322 & -0.240 & 2.859 \\
DLPROD_UK & 0.008 & -0.095 & -0.145 & -0.017 & 0.028 & -1.488 & -3.338 & -1.576 \\
DLPROD_US & -0.023 & -0.054 & 0.040 & -0.008 & -0.076 & -0.814 & 0.897 & -0.692
\end{tabular}

Test for exclusion: LR test chisq( $r)$

\begin{tabular}{|c|c|c|c|c|c|c|c|c|}
\hline & & 18 & & K & & & & \\
\hline 1 & 1 & 3.84 & 22.36 & 19.09 & 26.82 & 7.21 & 11.82 & 8.92 \\
\hline 2 & 2 & 5.99 & 22.39 & 23.00 & 29.73 & 10.90 & 12.56 & 10.86 \\
\hline 3 & 3 & 7.81 & 28.72 & 25.16 & 36.61 & 18.01 & 19.34 & 12.14 \\
\hline 4 & 4 & 9.49 & 47.94 & 34.40 & 54.89 & 36.12 & 36.14 & 14.50 \\
\hline 5 & 5 & 11.07 & 59.44 & 44.03 & 66.49 & 42.77 & 47.09 & 20.28 \\
\hline
\end{tabular}

Test for stationarity: LR test chisq(p-r)

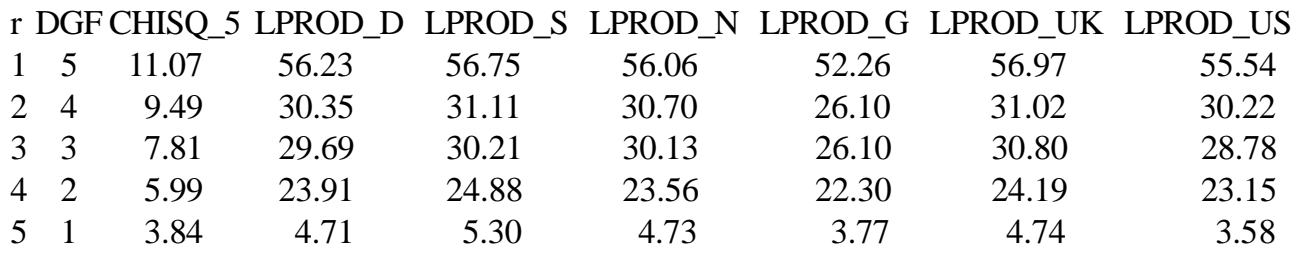

Test for weak-exogeneity: LR test chisq( $r)$

\begin{tabular}{|c|c|c|c|c|c|c|c|}
\hline & DGF CHISQ_5 LPROD_D & & LPROD_N & LPROD_G & LPROD_UK & \\
\hline \multicolumn{3}{|c|}{$\begin{array}{ccc}1 & 3.84 & 2.66\end{array}$} & 1.29 & $6.7 \overline{9}$ & $0 . \overline{6} 1$ & 0.00 & 0.00 \\
\hline 2 & 99 & 5.61 & 4.74 & 9.51 & 4.54 & 0.46 & 0.45 \\
\hline $\begin{array}{ll}2 & 2 \\
3 & 3\end{array}$ & $3 \quad 7.81$ & 12.23 & 10.87 & 9.58 & 8.07 & 5.46 & 1.12 \\
\hline 4 & 9.49 & 20.26 & 30.46 & 11.54 & 19.61 & 10.61 & 1.51 \\
\hline $\begin{array}{l}4 \\
5\end{array}$ & 11.07 & 30.68 & 40.67 & 12.77 & 30.10 & 18.58 & 13.10 \\
\hline
\end{tabular}

It is easy to reject the assumption of less than 3 cointegrating vectors among the six variables. The lambda max statistic leads us to accept four cointegrating vectors (two common trends), while the trace statistic suggests three vectors. A look at the companion matrix of the system, shows a relatively large fourth root which suggests that there might be four cointegrating vectors in the system.

The tests of exclusion, stationarity and weak exogeneity provide further information about the possible cointegrating vectors in the system. The tests of stationarity and exclusion show that accepting three or four vectors leads to the conclusions that all variables are I(1), and that no variable can be excluded from the system. The tests for weak exogeneity with respect to $\alpha$ and $\beta$ suggest that 
Table 7. Testing Cointegration between PPP and Productivity: Denmark

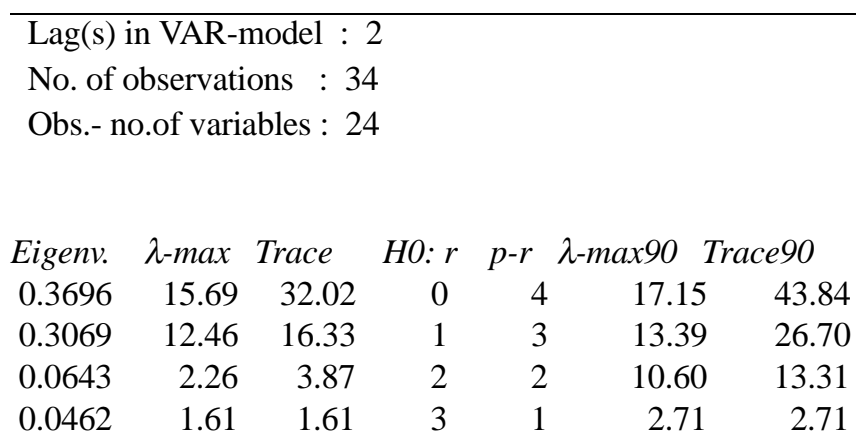

Test for autocorrelation

$\mathrm{L}-\mathrm{B}(8), \mathrm{CHISQ}(104)=126.88, \mathrm{p}-\mathrm{val}=0.06$

$\operatorname{LM}(1), \quad$ CHISQ $(16)=12.97, \mathrm{p}-\mathrm{val}=0.67$

$\operatorname{LM}(4), \quad$ CHISQ $(16)=11.58, \mathrm{p}-\mathrm{val}=0.77$

$\begin{array}{lrr}\begin{array}{l}\text { Test for normality } \\ \text { CHISQ(8) }\end{array} & =2.575, \mathrm{p}- \\ & & \\ & & \\ \text { ARCH(2) } & \text { Normality } & \text { R-squared } \\ 0.779 & 0.373 & 0.351 \\ 0.798 & 0.669 & 0.324 \\ 2.563 & 0.189 & 0.401 \\ 0.681 & 1.276 & 0.890\end{array}$

The eigenvalues of the companion matrix

$\begin{array}{crrr}\text { real } & \text { complex } & \text { modulus } & \text { argument } \\ 1.0560 & -0.0000 & 1.0560 & -0.0000 \\ 0.9699 & -0.0000 & 0.9699 & -0.0000 \\ 0.6297 & 0.4188 & 0.7563 & 0.5869 \\ 0.6297 & -0.4188 & 0.7563 & -0.5869 \\ 0.4348 & 0.3575 & 0.5629 & 0.6882 \\ 0.4348 & -0.3575 & 0.5629 & -0.6882 \\ -0.3565 & -0.0000 & 0.3565 & -3.1416 \\ 0.0715 & 0.0000 & 0.0715 & 0.0000\end{array}$

BETA (transposed)

\begin{tabular}{lcrc} 
RE_D & PDIF_D & RE_DG & PDIF_DG \\
1.000 & 0.871 & 3.441 & 1.602 \\
0.322 & 1.000 & -1.348 & 0.010 \\
\hline
\end{tabular}


Table 7. Continued

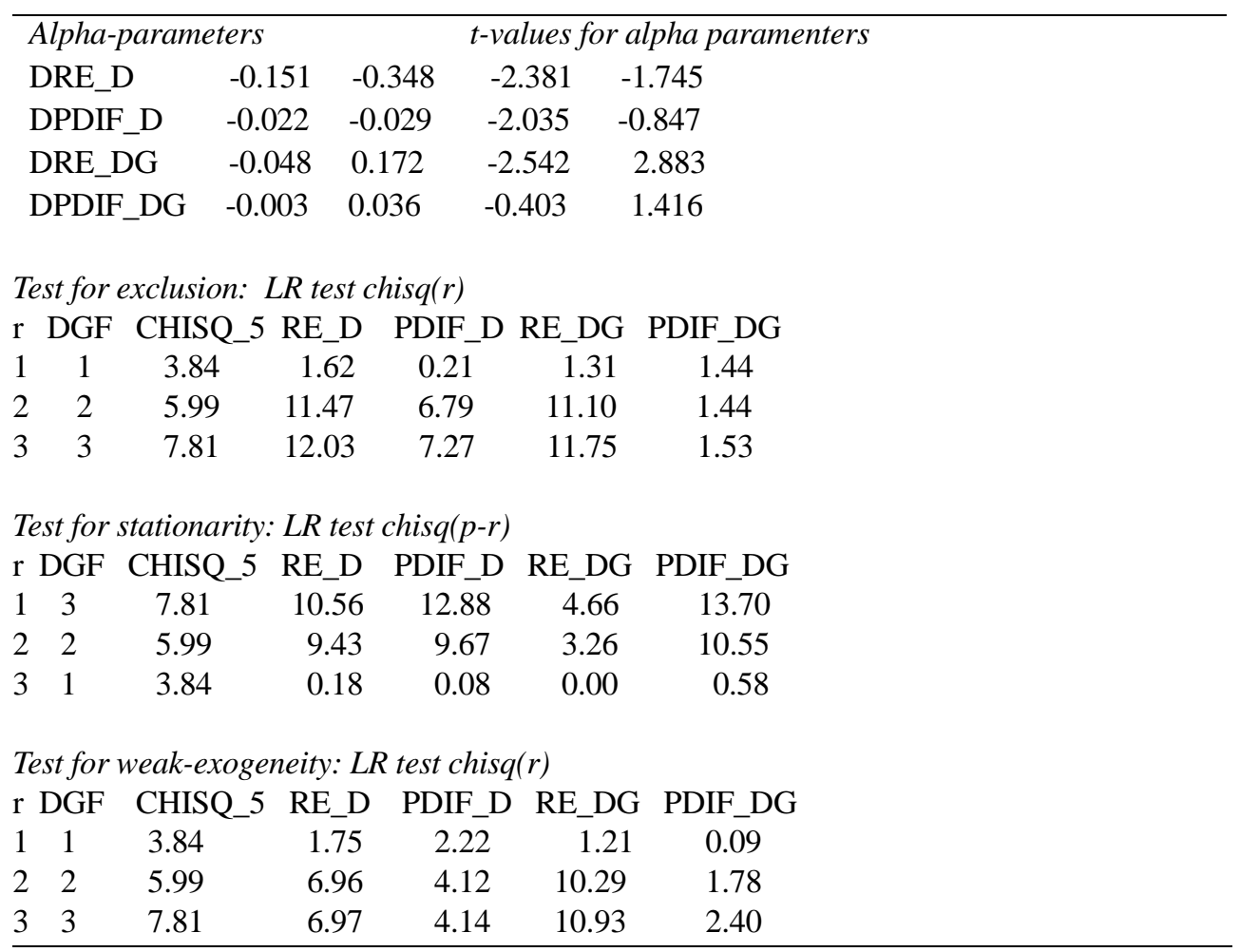

accepting three vectors is consistent with assuming three common trends; one European trend, one UK trend and one US trend. Accepting the hypothesis of four vectors leads to the conclusion that the UK trend is really a part of the European trend. Thus, with four cointegrating vectors in the system, productivity growth could be understood as driven by one European trend and one US trend. In this sample, the long-run US trend is exogenous to the European trend. In this sense, whatever problems there might be in constructing index series of productivity, the long-run behavior of these series seems consistent with our basic, a priori beliefs that they are driven by stochastic rather than deterministic trends, and that in an integrated world they share one or two common trends over time.

By looking at the significance of the alpha parameters we can perform a type of Granger causality test and ask which vector(s) predict productivity changes in which country. Sweden is the only country where productivity growth is predicted by all four vectors. Productivity growth in Denmark is predicted by vectors 1 to 3 , and in Germany is predicted by two vectors where the second vector is vector number four -a characteristic shared by Sweden only. Productivity growth in 
Table 8. Testing Cointegration between PPP and Productivity: Norway

\begin{tabular}{|c|c|c|c|c|c|c|}
\hline \multicolumn{7}{|c|}{$\overline{\operatorname{Lag}(\mathrm{s}) \text { in VAR-model }: 2}$} \\
\hline \multicolumn{7}{|c|}{ No. of observations $\quad: 34$} \\
\hline \multicolumn{7}{|c|}{ Obs.- no.of variables } \\
\hline Eigenv. & $\lambda-\max$ & Trace & $H O: r$ & $p-r$ & $\lambda-\max 90$ & Trace 90 \\
\hline 0.6348 & 34.25 & 50.86 & 0 & 4 & 17.15 & 43.84 \\
\hline 0.2979 & 12.03 & 16.61 & 1 & 3 & 13.39 & 26.70 \\
\hline 0.1129 & 4.07 & 4.59 & 2 & 2 & 10.60 & 13.31 \\
\hline 0.0150 & 0.51 & 0.51 & 3 & 1 & 2.71 & 2.71 \\
\hline
\end{tabular}

Test for autocorrelation

$\mathrm{L}-\mathrm{B}(8), \mathrm{CHISQ}(108)=131.780, \mathrm{p}-\mathrm{val}=0.06$

$\operatorname{LM}(1), \operatorname{CHISQ}(16)=13.196, \quad \mathrm{p}-\mathrm{val}=0.66$

$\operatorname{LM}(4), \quad \operatorname{CHISQ}(16)=11.426, \quad \mathrm{p}$-val $=0.78$

$\begin{array}{lcr}\begin{array}{l}\text { Test for normality } \\ \text { CHISQ(8) }\end{array} & \\ & & \\ & & \\ & & \\ \text { ARCH(2) } & \text { Normality } & \text { R-squared } \\ 0.672 & 2.046 & 0.501 \\ 0.787 & 8.197 & 0.159 \\ 0.988 & 9.315 & 0.289 \\ 2.334 & 0.187 & 0.732\end{array}$

The eigenvalues of the companion matrix

real complex modulus argument

$\begin{array}{rrrr}0.9770 & 0.0000 & 0.9770 & 0.0000 \\ 0.9354 & 0.0000 & 0.9354 & 0.0000 \\ 0.5967 & -0.4166 & 0.7277 & -0.6095 \\ 0.5967 & 0.4166 & 0.7277 & 0.6095 \\ 0.1244 & 0.3557 & 0.3768 & 1.2344 \\ 0.1244 & -0.3557 & 0.3768 & -1.2344 \\ 0.2018 & -0.0000 & 0.2018 & -0.0000 \\ -0.0843 & -0.0000 & 0.0843 & -3.1416\end{array}$

BETA (transposed)

RE_N PDIF_N RE_NG PDIF_NG

$\begin{array}{llll}1.000 & 1.119 & 2.018 & 3.490\end{array}$


Table 8. Continued

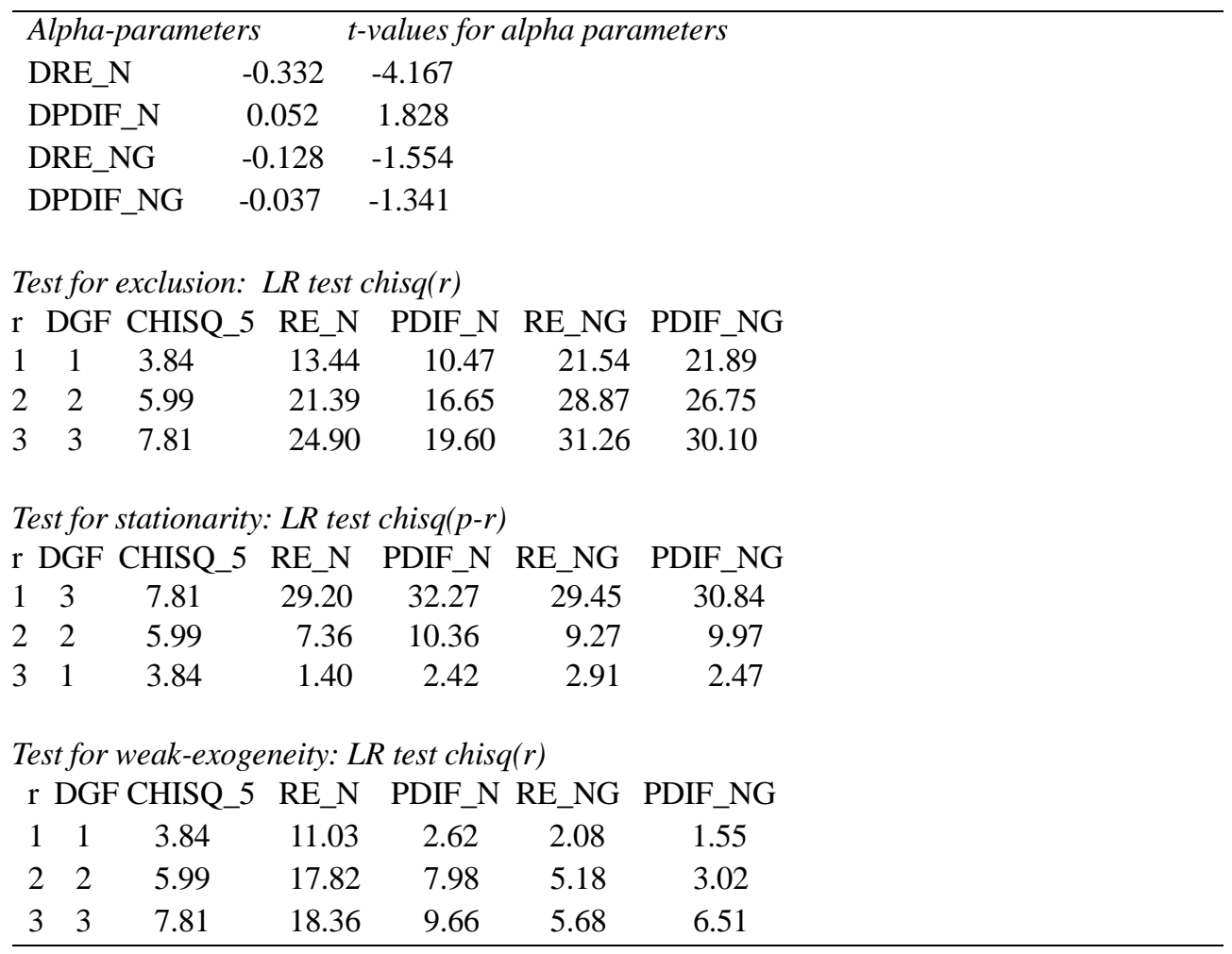

Norway and the UK are only predicted by one (different) vector in each country. Finally, a consequence of not rejecting weak exogeneity of the US productivity is that no vector is able to predict the US productivity growth.

Against this background, our hypothesis is that the most of the real exchange rate series and the series measuring the productivity gaps are integrated of order one. We now turn to the question of whether real exchange rates cointegrate with productivity differences. For each country we estimate a VECM of order two, including a dummy variable for 1991 which captures the German reunification effect on productivity. Most models reject the assumption of residual autocorrelation, up to 8 lags, using the Ljung-Box statistics. But, given the limited sample, it is difficult to compensate for this by increasing the order of the VAR. As will be shown by the results, the main problem for finding support for the productivitybias hypothesis lies in the signs of the long-run relationships that are found in these VECMs.

For Denmark, Table 7, we find two cointegrating vectors. Judging from the test 
Table 9. Testing Cointegration between PPP and Productivity: Sweden

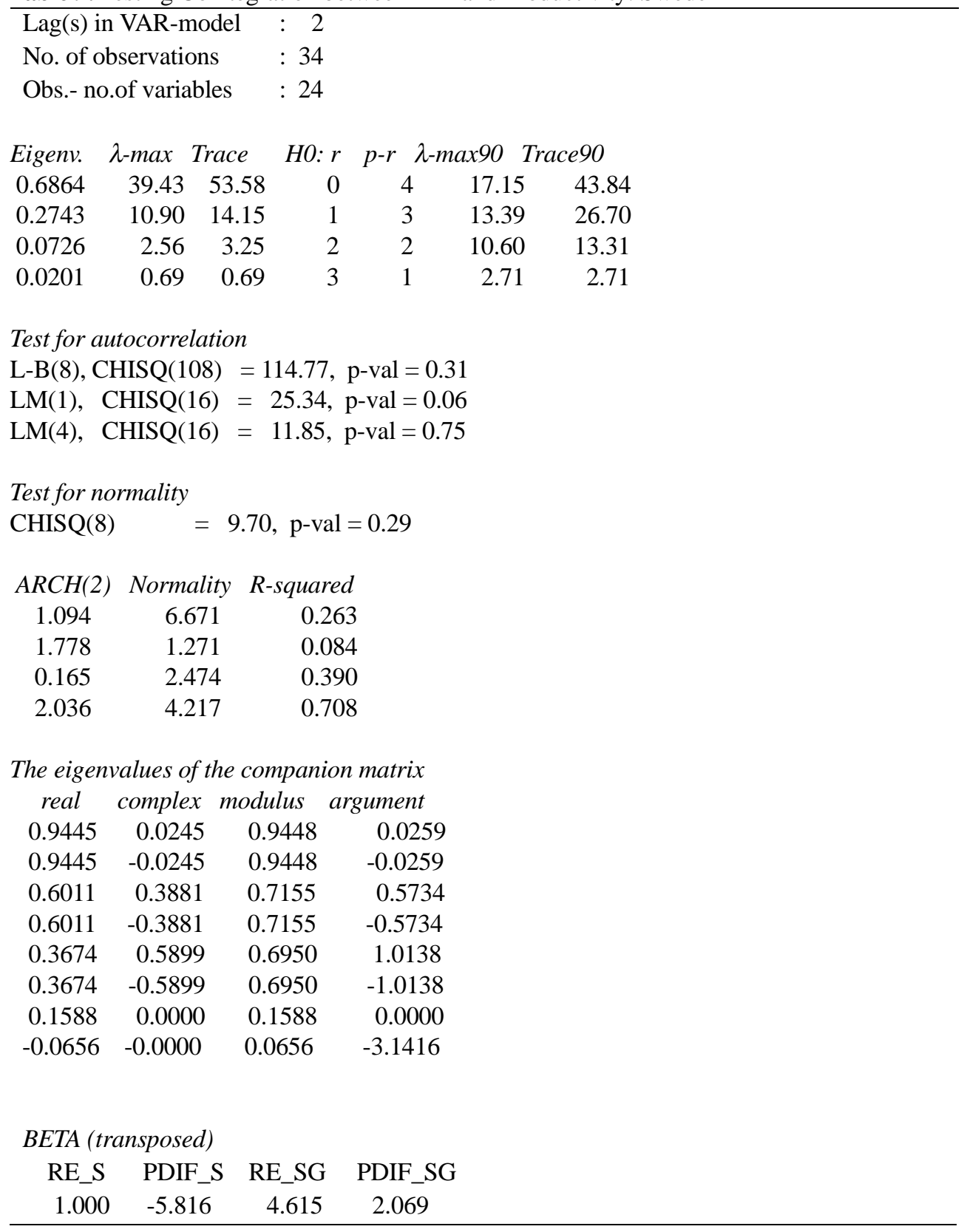


Table 9. Continued

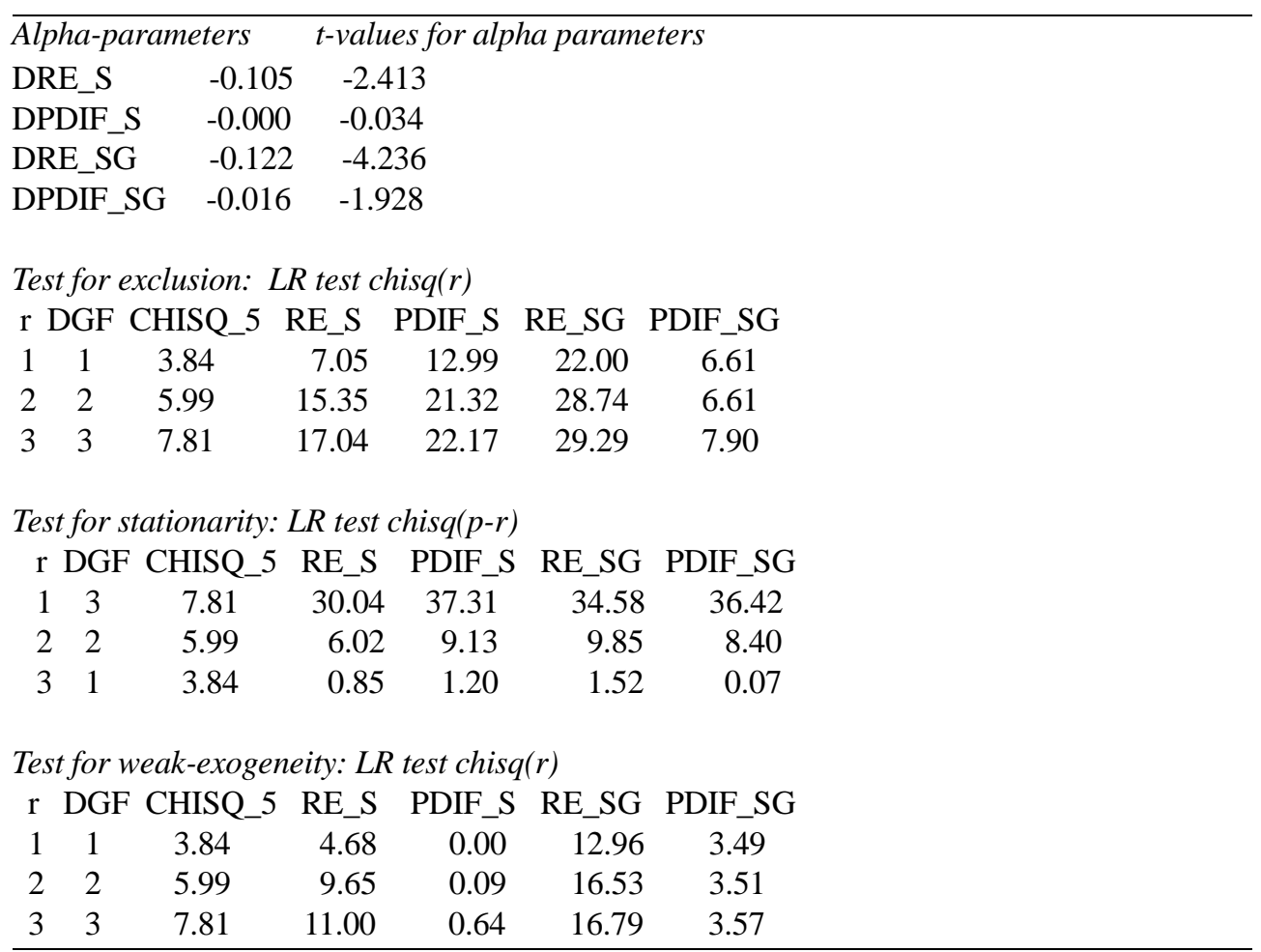

for stationarity, one of these vectors is the Danish real DM rate. The other vector, looking at the exclusion test for $r=2$, consists of the real USD rate in combination with the productivity gap between Denmark and the US, and the real DM rate. It is the combination of productivity gaps and real exchange rates that produces cointegrating vectors in the Danish data set. However, the problem for the productivity-bias hypothesis lies in the signs of the parameters. The hypothesis suggests that real exchange rates and the productivity series should have opposite signs but that is not the case here.

For Norway, Table 8, there is one cointegrating vector, a result consistent with the outcomes from the various batch tests. ${ }^{2}$ The test statistics show that there is a problem with the assumption of normally distributed residuals for the productivity gap with respect to the US and for the real DM equation. The signs of the beta parameters in the cointegrating vector are positive and do not support the productivity-bias hypothesis.

\footnotetext{
${ }^{2}$ Though the roots of the companion matrix suggest a second vector, we have chosen $r=1$.
} 
Table 10. Testing Cointegration between PPP and Productivity: UK

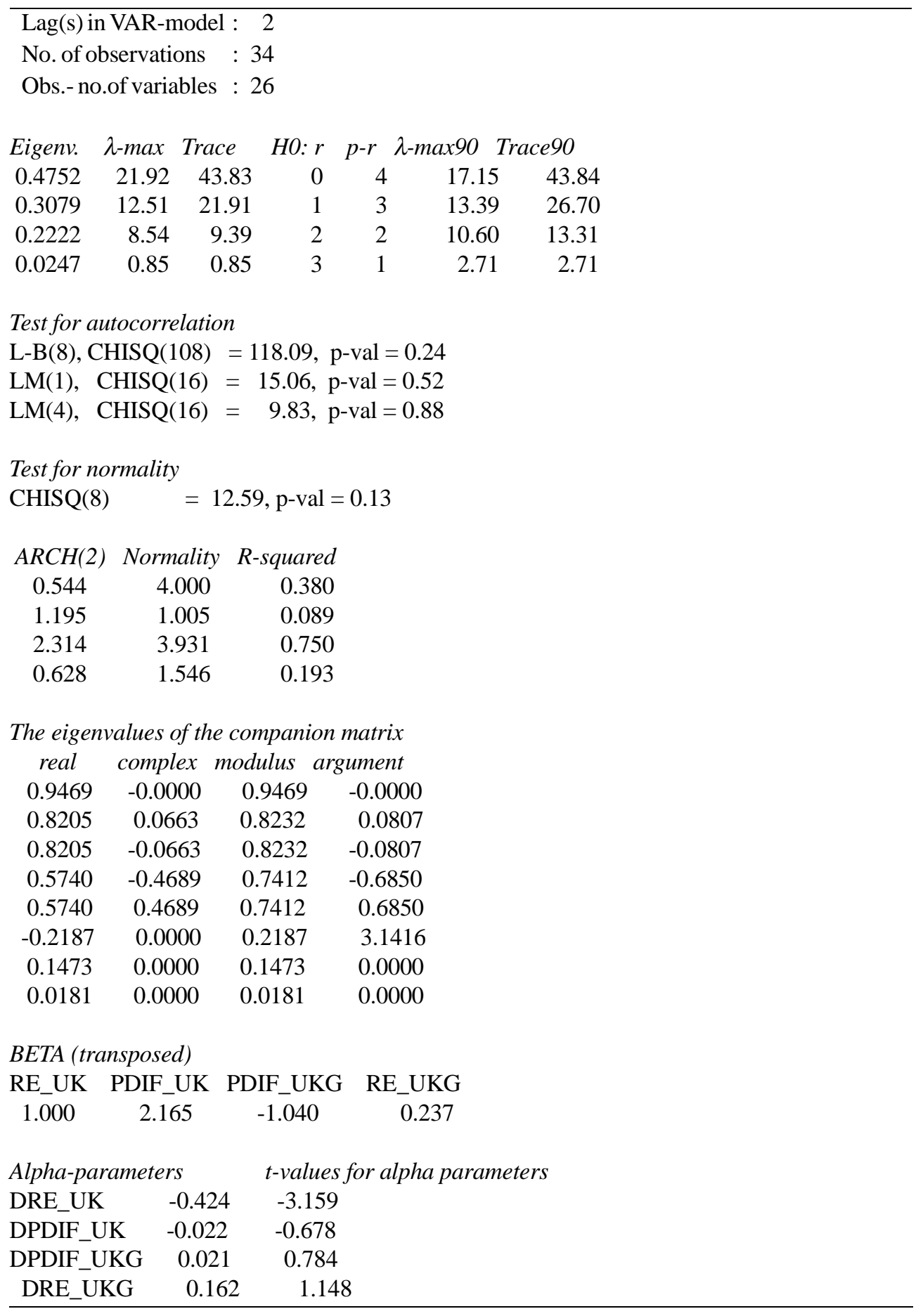


Table 10. Continued

\begin{tabular}{|c|c|c|c|c|c|}
\hline \multicolumn{6}{|c|}{ Test for exclusion: LR test chisq(r) } \\
\hline r DGF & CHISQ_5 & RE_UK & PDIF_UK & PDIF_UKG & RE_UKG \\
\hline 11 & 3.84 & 9.01 & 6.89 & 3.91 & 1.03 \\
\hline 22 & 5.99 & 12.71 & 8.60 & 3.95 & 5.00 \\
\hline 33 & 7.81 & 20.06 & 13.37 & 9.71 & 10.15 \\
\hline \multicolumn{6}{|c|}{ Test for stationarity: LR test chisq(p-r) } \\
\hline r DGF & CHISQ_5 & RE_UK & PDIF_UK & PDIF_UKG & RE_UKG \\
\hline 13 & 7.81 & 13.80 & 17.58 & 15.74 & 15.20 \\
\hline 22 & 5.99 & 10.10 & 8.20 & 6.45 & 5.97 \\
\hline 31 & 3.84 & 7.58 & 5.57 & 2.95 & 3.73 \\
\hline \multicolumn{6}{|c|}{ Test for weak-exogeneity: LR test chisq(r) } \\
\hline r DGF & CHISQ_5 & RE_UK & PDIF_UK & PDIF_UKG & RE_UKG \\
\hline 11 & 3.84 & 5.67 & 0.40 & 0.34 & 1.03 \\
\hline 22 & 5.99 & 6.21 & 0.54 & 3.99 & 2.39 \\
\hline 33 & 7.81 & 12.86 & 2.09 & 9.29 & 3.70 \\
\hline
\end{tabular}

For Sweden, Table 9, we find one cointegrating vector. Unlike the vectors for Denmark and Norway, the Swedish vector has opposite signs for the parameters of the real USD rate and the productivity gap against the US, in line with the productivity-bias theory. However, it is not possible to exclude the real DM rate and the German productivity gap from the equation. These two variables have positive parameters that are not easily identified as an economically meaningful relationship.

For the UK, Table 10, we find one cointegrating vector. The exclusion test suggests that the real DM rate can be left out, leaving us with a stationary vector of three variables; the real USD rate and the two productivity differentials. Again the signs of the parameters do not have a clear economic interpretation.

Finally, for Germany, Table 11, the model that is most consistent with the data consists of the real USD rate, the productivity series for Germany and the US, separately, and a time trend in the cointegrating vector. However, this model has problems with the Ljung-Box test and the assumption of normally distributed residuals. The problems concerning normality come from the real DM equation, even though we have included a dummy for 1991. The model has two cointegrating vectors. One of the vectors is made up the German productivity series which becomes stationary in this model. The other cointegrating vector therefore consists of the real USD rate, the US productivity series and a time trend. If the time trend is capturing the long-run productivity trend in Germany, as the 
Table 11. Testing Cointegration between PPP and Productivity: Germany

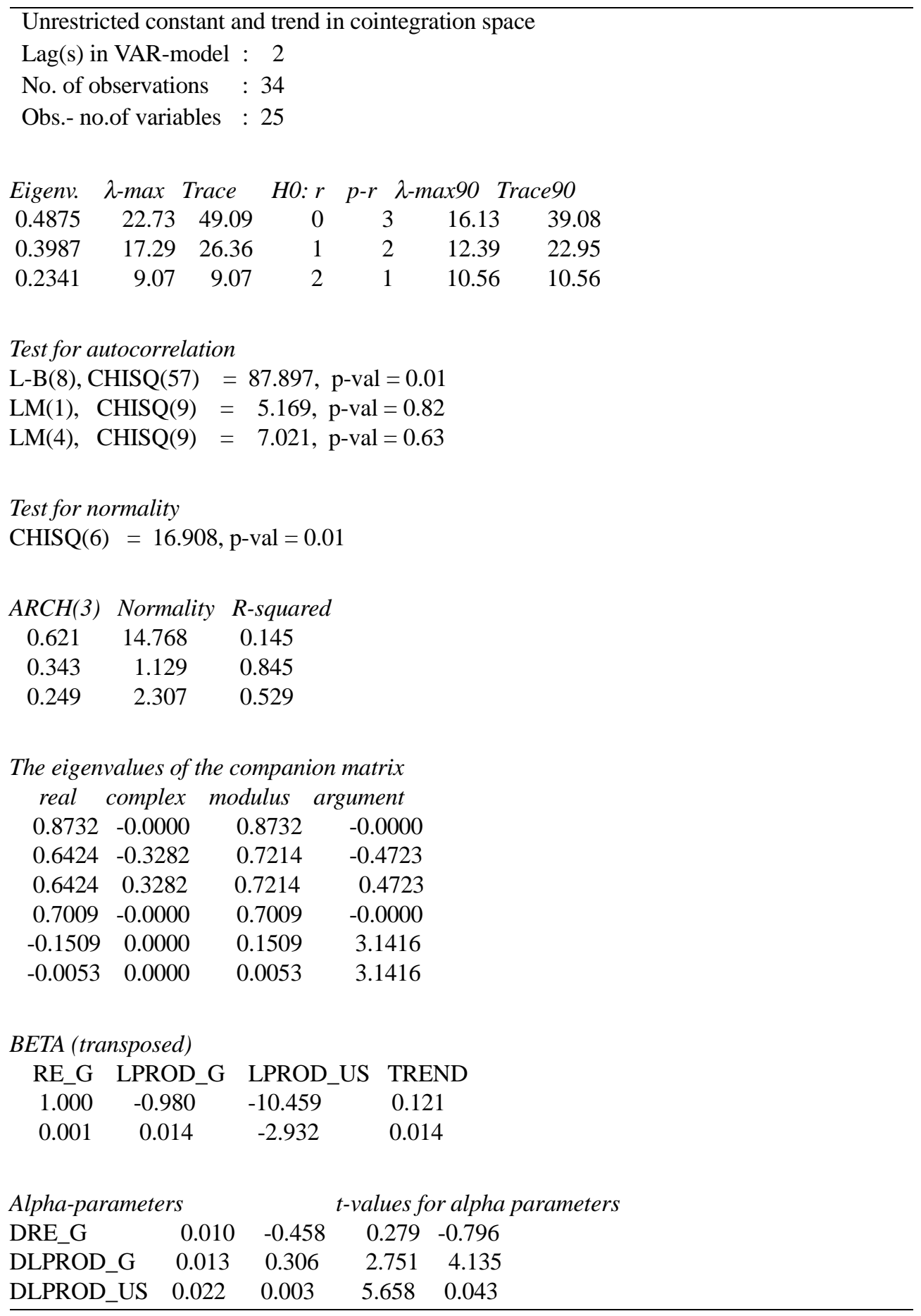


Table 11. Continued

\begin{tabular}{|c|c|c|c|c|c|}
\hline \multicolumn{6}{|c|}{ Test for exclusion: LR test chisq(r) } \\
\hline r DGF & CHISQ_5 & RE_G & LPROD_G & LPROD_US & TREND \\
\hline 11 & 3.84 & 1.73 & 0.15 & 1.69 & 3.82 \\
\hline 22 & 5.99 & 1.73 & 7.53 & 9.67 & 11.94 \\
\hline \multicolumn{6}{|c|}{ Test for stationarity: LR test chisq(p-r) } \\
\hline r DGF & CHISQ_5 & RE_G & LPROD_G & LPROD_US & \\
\hline 13 & 7.81 & $8 . \overline{5} 6$ & 5.93 & 8.73 & \\
\hline 22 & 5.99 & 6.55 & 3.47 & 7.44 & \\
\hline \multicolumn{6}{|c|}{ Test for weak-exogeneity: LR test chisq(r) } \\
\hline r DGF & CHISQ_5 & RE_G & LPROD_G & LPROD_US & \\
\hline 11 & 3.84 & $0 . \overline{0} 5$ & 1.36 & 5.43 & \\
\hline 22 & 5.99 & 0.39 & 9.54 & 13.57 & \\
\hline
\end{tabular}

Dickey-Fuller test in Table 2 suggests, the signs of the beta parameters are in line with productivity-bias hypothesis.

\section{Conclusions}

In this paper we test the Balassa-Samuelson effect or the productivity-bias hypothesis, applying cointegration techniques to a sample of yearly data that includes the real exchange rates and productivity series for six OECD countries. The real exchange rates series, the productivity series, and bivariate productivity differentials can, in most, cases be assumed to be integrated of order one. We find little support for the productivity bias-hypothesis in our sample. Bivariate models generally fit the data quite badly. Extending the VAR models to include both the DM and the USD real rates and productivity gaps lead to models that are more consistent with the data chosen, though not perfect. These models also display cointegrating relationships among real exchange rates and productivity differences. Although the parameters of the estimated cointegrating vectors are not tested statistically, we conclude on the basis of their signs that they are not easily identified as those predicted by the Balassa-Samuelson effect.

This negative result could be due to the fact that the tests of the BalassaSamuelson effect for explaining long-run real exchange rates or deviations from PPP are made mainly through bilateral comparison. It might be that the effect is more dominant for properly defined real effective exchange rates. Furthermore, our sample spans different exchange rate regimes, from fixed Bretton-Woods 
system over the flexible snake-period and the European Monetary System (EMS) periods up until today's floating system. There are substantial differences in real exchange rate behavior across exchange rate regimes (Mussa, 1986, 1990). That is, exchange rate regimes that are officially fixed indicate substantially low real variability compared to those that are allowed to float more or less freely. Flood and Rose (1993) show that the volatility of the exchange rate during a regime of floating is between three and nine times as volatile as during a fixed exchange rate regime. Mussa explains a variety of reasons for exchange rate regime-specific differences in real exchange rate behavior. These are speculative bubbles, sticky prices, systematically varying macroeconomic shocks, or regime-specific differences in policy behavior. Finally, the other reason for the inconclusive result probably lie in the definition of productivity variable which is only labor productivity rather than total factor productivity. The labor productivity is not a complete measure of productivity and more important it may pick up business cycle frequencies.

Our results have implications for monetary integration in Europe. In the European Monetary Integration (EMU), by definition, there will be no possibility of currency realignment to offset adverse output and employment effects. This implies that in a monetary union with a single currency, the output and employment effects of relatively slow productivity growth and declining competitiveness over the long run could cause agitation for the reassertion of monetary sovereignty and offsetting exchange rate adjustment. Thus, the convergence criteria for a monetary union should consider differential productivity growth. Furthermore, in the EMU membership, adjustment that might be needed to offset the competitive effects of productivity differentials over long periods must be internal, such as wage flexibility. And the more inflexible labor markets, the more problematic is the effect of productivity differentials in the EMU-area. Generally speaking, these conflicting forces and the deviation of the productivitymodified PPP from the equilibrium exchange rate could be a threat to the EMU.

\section{Acknowledgements}

We thank three anonymous referees and the editor of this journal for their helpful comments and suggestions. Any remaining errors are our own.

Date accepted: March 2001 


\section{References}

Balassa, B. (1964) "The purchasing power parity doctrine: A reappraisal", The Journal of Political Economy 72, 584-596.

Cassel, G. (1916) "The present situation of foreign exchanges", Economic Journal 26, 6265.

De Gregorio, J., A. Giovannini, and H. Wolf (1994) "International evidence on tradable and nontradables inflation", European Economic Review 38, 1225-1244.

Edison, H. and J. T. Klovland (1987) "A quantitative reassessment of the purchasing power parity hypothesis: Evidence from Norway and the United Kingdom", Journal of Applied Econometrics 2, 309-333.

Flood, R. A. and A. K. Rose (1993) "Fixing exchange rate", NBER Working Paper No. 4503.

Froot, K. and K. Rogoff (1991a) "The EMS, the EMU, and the transition to a common currency", in S. Fisher and O. Blanchard, eds., National bureau of economic research macroeconomics annual (MIT Press, Cambridge, MA) 269-317.

Froot, K. and K. Rogoff (1991b) "Government consumption and the real exchange rate: The empirical evidence", mimeo, Harvard Business School.

Froot, K. and K. Rogoff (1995) "Perspectives on PPP and long-run real exchange rates", in G. Grossman and K. Rogoff, eds., Handbook of International Economics, vol. III.

Hendry, D. F. and J. A. Doornik (1996) Empirical Modelling using PcGive for Windows, London, International Thomson Business.

Hsieh, D. (1982) "The determination of the real exchange rate: The productivity approach", Journal of International Economics 12, 355-362.

Johansen, S. (1988) "Statistical analysis of cointegration vectors," Journal of Economic Dynamics and Control 12, 231-254.

Johansen, S. and K. Juselius (1990) "Maximum likelihood estimation and inference on cointegration -with application to the demand for money", Oxford Bulletin of Economics and Statistics 52, 169-210.

Mark, N. C. and D. Y. Choi (1997) "Real exchange-rate prediction over long horizons", Journal of International Economics 43, 29-60.

Marston, R. (1987) "Real exchange rates and Productivity growth in the United States and Japan", in S. Arndt and J. D. Richardson, eds., Real-Financial linkages among open economies (MIT Press, Cambridge, MA).

Mussa, M. (1986), "Nominal exchange rate regimes and the behavior of the real exchange rate", in K. Brunner and A. H. Meltzer, eds., Real business cycles, real exchange rates and actual policies (North-Holland, New York) 117-213.

Mussa, M. (1990) "Exchange rates in theory and in reality", Essays in International Finance No. 179 (Princeton University, Princeton, NJ).

Obstfeld, M. (1993) "Modelling trending real exchange rates", Centre for International and Development Economics Research Working Paper No. C93-011, University of 
California at Berkeley.

Officer, L. H. (1976) "The productivity bias in purchasing power parity: An econometric investigation", International Monetary Funds Staff Papers 10, 545-579.

Rogers, J. H. (1995) "Real shocks and real exchange rates in really long-run data", Working Paper (Federal Reserve Board).

Rogers, J. H. and M. Jenkins (1995) "Haircuts or hysteresis? Sources of movements in real exchange rates", Journal of International Economics 38, 339-360.

Rogoff, K. (1992) "Traded goods consumption smoothing and the random walk behaviour of the real exchange rate", NBER Working Paper No. 4119.

Samuelson, P. A. (1964) "Theoretical notes on trade problems", Review of Economics and Statistics 46, 145-164.

Sims, C. A., J. H. Stock, and M. W. Watson (1990), "Inference in linear time series models with some unit roots", Econometrica 58, 113-144. 